\title{
Physicochemical and antioxidant properties in Allium hookeri by hot air-and freeze-drying methods
}

\author{
Joomin Lee* \\ Department of Food and Nutrition, Chosun University, Gwangiu 61452, Korea \\ 건조방법에 따른 삼채의 이화학적 성분 및 항산화 활성 비교 \\ 이주민* \\ 조선대학교 식품영양학과
}

\begin{abstract}
The present study was undertaken to determine the changes of physicochemical and antioxidant activity using leaf and root in hot air-dried Allium hookeri (HA) and freeze-dried Allium hookeri (FA). The leaf of HA was higher level of moisture and crude fat compared with those of the leaf of FA. The crude fat content in root of HA was higher than that in FA. However, moisture, crude ash, crude protein and carbohydrate did not show any differences between two different drying methods. The organic acid contents of Allium hookeri root including oxalic acid, citric acid, tartaric acid, malic acid, succinic acid, lactic acid, formic acid, acetic acid showed the differences between hot air-drying and freeze-drying methods. The major minerals were $\mathrm{Ca}, \mathrm{K}$ and $\mathrm{Mg}$, which were higher level of the leaf of HA compared with those of FA. The leaf of HA showed the highest vitamin C content $(801.65 \mathrm{mg} / 100$ g). The content of vitamin $E$ in the leaf of $F A$ was higher than that of HA. The contents of total polyphenol and total flavonoid in the FA leaf were higher than that in HA. The DPPH radical-scavenging activity in leaf of HA $(65.73 \%)$ was significantly higher than that of FA $(57.73 \%)$.
\end{abstract}

Key words : Allium hookeri, physicochemical analysis, antioxidant effect

\section{서 론}

삼채(Allium hookerr)는 백합과에 속하는 다년생 식물로 뿌리 부추라고도 불린다. 단맛, 쓴맛, 매운맛을 낸다하여 삼채로 불리고, 히말라야 산맥 해발 $1,400 \mathrm{~m}$ 이상의 초원지 대에 자생하며, 미얀마, 중국, 인도, 부탄, 스리랑카 등지에 서 주로 약용식물로 섭취되고 있다(1). Allium 속 식물들은 삼채를 포함하여 부추, 마늘, 양파 등이 있으며, 이들은 항산 화, 항균, 항암 등에 효과적이라는 보고가 있다(2,3). 삼채의 잎과 뿌리에 있는 주요 성분으로는 알리신과 같은 함황성분 과 폐놀성화합물을 포함한 여러 생리활성 물질들을 포함하

*Corresponding author. E-mail : joominlee@chosun.ac.kr Phone : 82-62-230-7722; Fax : 82-62-225-7726

Received 2 November 2015; Revised 7 December 2015; Accepted 7 January 2016.

Copyright (c) The Korean Society of Food Preservation. All rights reserved.
고 있다(4-6)

지금까지 삼채에 관한 연구는 국내 및 미얀마 지역이나 노지 및 시설에서 재배된 삼채의 잎과 뿌리를 이용한 일반 성분 분석 및 항산화 효능 등이 있다(7,8). 또한 삼채의 건조 방식 및 추출방식에 따른 항산화 효과 및 영양, 화학적 분석 등도 보고되었다 $(9,10)$.

수확한 삼채의 품질보존을 높이기 위해, 건조 시간을 빠 르게 하여 영양성분의 파괴를 최소화하기 위한 여러 가공방 법들이 있으며, 이중 인공건조법으로는 열풍, 동결, 냉풍 등의 방법이 있다(11). 동결건조는 건조하고자 하는 재료를 낮은 온도로 동결 시킨 후, 건조기의 내부를 진공 상태로 만들어 얼음을 승화시키는 방법이다(12). 열풍건조는 동결 건조에 비해 공정이 간단하고 건조시간이 빠르며 경제적이 나 빠른 수분 손실로 인한 수축 등으로 색상, 조직감, 맛 및 영양가 등에서 품질적 열화가 문제될 수 있다(13).

본 연구에서는 국내산 삼채를 잎과 뿌리로 분리하고, 열 풍건조 및 동결건조 방법을 통해 이화학적 성분 및 항산화 
성분의 변화를 비교 분석하고자 한다. 이에 건조 방법에 따라 국내산 삼채의 영양 손실을 최소화 시킬 수 있는 효율 적인 방법을 찾고, 식품으로서의 이용 가치를 높이기 위한 기초 자료를 제시하고자 한다.

\section{재료 및 방법}

\section{실험재료}

본 실험에 사용된 삼채 잎과 뿌리는 전라남도 장성군에 서 2015년 6월에 구입하였으며, 수세한 후, 물기를 제거하 여 실온에서 완전히 건조시켰다. 건조된 삼채 잎과 뿌리를 각각 분쇄기로 분쇄한 후, $-70^{\circ} \mathrm{C}$ 에 보관하여 사용하였다.

\section{건조방법}

열풍건조를 위해 삼채 잎과 뿌리를 각각 열풍건조기 (GNO12, Hanil GNCO Co., Ltd., Jangseong, Korea)를 이용 하여 $60^{\circ} \mathrm{C}$ 에서 40 시간 건조시켰다. 동결건조를 위해 삼채 잎과 뿌리는 $-70^{\circ} \mathrm{C}$ deep freezer(MDF-U52V, Sanyo, Osaka, Japan)에서 냉동시킨 후 동결 건조기(ED 8512, Ilshin, Yangju, Korea)를 이용하여 $-70^{\circ} \mathrm{C}$ 에서 72 시간 건조시켜 이 용 하였다. 열풍건조 및 동결건조 된 삼채의 잎과 뿌리는 분쇄기로 $20 \mathrm{mesh}$ 로 마쇄 후 $-70^{\circ} \mathrm{C}$ 에 냉동보관하여 이용하 였다.

\section{시료추출}

삼채 분말 $100 \mathrm{~g}$ 당 $1.5 \mathrm{~L} 80 \%$ 에탄올, $1.2 \mathrm{~L}$ 에탄올, $0.3 \mathrm{~L}$ 증류수를 각각 첨가한 후 환류냉각관을 부착한 $65^{\circ} \mathrm{C}$ 의 heating mantle(Mtops ms-265, Seoul, Korea)에서 3시간씩 3 회 추출하였다. 추출한 삼채 잎과 뿌리 추출액을 Whatman filter paper(No.2, GE Heathcare, Buckinghamshire, UK)를 이용하여 여과하였다. 여액을 $40^{\circ} \mathrm{C}$ 수욕 상에서 rotary vacuum evaporator(EYELA VACUUM NVC-1100, Tokyo, Japan)로 용매를 제거하고 감압 - 농축한 다음 동결 건조시 켰으며, 시료의 산화를 방지하기 위해 $-70^{\circ} \mathrm{C}$ 에 냉동 보관하 면서 사용하였다.

\section{일반성분 분석}

일반성분은 Association of Official Analytical Chemists (AOAC) 방법(14) 따라 수분함량은 $105^{\circ} \mathrm{C}$ 건조법, 조지방은 Soxhlet법, 회분은 $550^{\circ} \mathrm{C}$ 회화법으로 분석하였고 조단백질 은 원소분석기(Thermo Quest사, Flash 2000, Milano, Italy) 를 이용하여 전질소량을 정량하고 질소계수 6.25 를 곱하여 조단백질로 하였으며, 탄수화물은 100 에서 수분, 조단백질, 조지방, 회분의 값을 제한 값으로 하였다.

\section{유기산 함량 측정}

유기산 분석은 $\mathrm{Kim}$ 등의 방법(15)에 따라 시료 $0.5 \mathrm{~g}$ 를
취하여 cap이 달린 삼각플라스크에 넣고 증류수 $20 \mathrm{~mL}$ 를 가하고, $80^{\circ} \mathrm{C}$ 이상의 온도로 맞춘 항온수조에 4 시간동안 교반 및 추출한 후 $3,000 \mathrm{rpm}$ 에서 20 분간 원심분리하였다. 상등액을 whatman membrane filter $(1 \mu \mathrm{m})$ 로 여과시킨 후

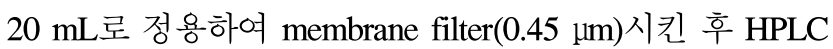
로 분석하였다.

\section{비타민 분석}

비타민 $\mathrm{C}$ 와 비타민 $\mathrm{E}$ 분석은 식품공전법의 시험방법을 기준으로 수행하였다(16). 비타민 C 함량은 각 추출물을 $0.2 \mu \mathrm{m}$ membrane filter로 여과하여 high-performance liquid chromatography(HPLC)(Young-Rin Associates, Seoul, Korea) 로 분석 하였으며, 분석조건으로 column은 $\mu \mathrm{Bondapak} \mathrm{C} 18$ $(3.9 \times 300 \mathrm{~mm}, 10 \mu \mathrm{m})$ 을 사용하였고, 유속은 solvent 30 $\mathrm{mL} / \mathrm{hr}$, ninhydrin $20 \mathrm{~mL} / \mathrm{hr}$, 압력은 solvent $55 \mathrm{bar}$, ninhydrin $12 \mathrm{bar}$ 이었다. 비타민 $\mathrm{E}$ 분석은 시료 $0.5 \mathrm{~g}$ 에 ascorbic acid $0.1 \mathrm{~g}$ 과 ethanol $5 \mathrm{~mL}$ 를 첨가하여 균질화한 후 $80^{\circ} \mathrm{C}$ 에서 10 분간 추출한 다음 $50 \% \mathrm{KOH}$ 용액을 $0.25 \mathrm{~mL}$ 첨가하고 증류수 $24 \mathrm{~mL}$ 와 hexane $5 \mathrm{~mL}$ 를 가하여 $3,000 \mathrm{rpm}$ 에서 20 분 간 원심분리하였다. 상징액에 hexane $40 \mathrm{~mL}$ 을 가하고 10 분 방치 후 하층을 제거하였다. 이 과정을 3회 반복 실행한 후, 전 상등액을 합하여 무수황산나트륨을 가해 탈수시킨 후 rotary vacuum evaporator로 hexane을 $3 \mathrm{~mL}$ 까지 감압 · 농 축한 후 HPLC(LC-10Avp Shimadzu, Kyoto, Japan)로 분석 하였다.

\section{무기질 분석}

무기질 분석은 $\mathrm{AOAC}$ 방법(14)에 따라 시료 $0.5 \mathrm{~g}, 20 \%$ $\mathrm{HNO}_{3} 10 \mathrm{~mL}$ 및 $60 \% \mathrm{HClO}_{4} 3 \mathrm{~mL}$ 를 취하여 투명해질 때까 지 가열한 후 $0.5 \mathrm{M} \mathrm{HNO}_{3}$ 으로 $50 \mathrm{~mL}$ 로 정용하였다. 분석항 목별 표준용액을 혼합 후 다른 vial에 $8 \mathrm{~mL}$ 씩 취하여 표준용 액으로 하였고 $0.5 \mathrm{M} \mathrm{HNO}_{3}$ 을 대조구로 하여 원자흡수분광 광도계(AA-6501GS, Shimadzu, Kyoto, Japan)로 분석하였 으며 분석조건은 다음과 같다. Acetylene flow rate는 2.0 $\mathrm{L} / \mathrm{min}$, air flow rate는 $13.5 \mathrm{~L} / \mathrm{min}$ 의 조건으로 $\mathrm{Ca}(317.9 \mathrm{~nm})$, $\mathrm{K}(766.5 \mathrm{~nm}), \operatorname{Mg}(285.2 \mathrm{~nm}), \mathrm{Fe}(238.2 \mathrm{~nm}), \mathrm{Cu}(327.4 \mathrm{~nm})$, $\mathrm{Mn}(257.6 \mathrm{~nm}), \mathrm{Zn}(206.2 \mathrm{~nm}), \mathrm{P}(213.6 \mathrm{~nm}), \mathrm{Na}(589.6 \mathrm{~nm})$ 을 분석 정량하였다.

\section{총 polyphenol 함량}

부위별 삼채 에탄올 추출물의 총 polyphenol 함량은 Folin-Denis법(17)에 따라 측정하였다. Test tube에 삼채 추 출물과 Folin reagent를 각각 $0.5 \mathrm{~mL}$ 씩 담아 실온에서 3 분간 정치한 다음 $10 \% \mathrm{Na}_{2} \mathrm{CO}_{3} 0.8 \mathrm{~mL}$ 을 첨가한 후 40 분간 정치 하였으며, UV-spectrophotometer(Bio-rad, Hercules, USA)를 사용하여 $760 \mathrm{~nm}$ 에서 흡광도를 측정하였다. 표준곡선은 tannic acid를 이용하여 최종 농도가 $0,6.25,12.5,25,50$, 
$100 \mathrm{ppm}$ 이 되도록 작성하였으며, 이 검량곡선으로부터 시 료 중의 총 polyphenol 함량을 구했다.

\section{총 flavonoid 함량}

총 flavonoid 함량은 Davis법을 변형한 방법(18)에 따라 측정하였다. 삼채 추출물과 diethylene glycol을 각각 0.5 $\mathrm{mL}$ 를 첨가한 다음, $1 \mathrm{~N} \mathrm{NaOH} 10 \mu \mathrm{L}$ 을 넣고 $37^{\circ} \mathrm{C}$ water bath에서 1시간 동안 반응시킨 후 UV-spectrophotometer (Bio-rad)로 $420 \mathrm{~nm}$ 에서 흡광도를 측정하였다. 표준곡선은 rutin을 이용하여 최종 농도가 $0,6.25,12.5,25,50,100$ $\mathrm{ug} / \mathrm{mL}$ 이 되도록 조제하였으며, 이 검량곡선으로부터 시료 중의 flavonoid 함량을 구했다.

\section{DPPH radical 소거능}

삼채 추출물의 2,2-diphenyl-1-picrylhydrazyl(DPPH) radical 소거능은 Blois(19)의 방법을 이용하여 측정하였다. 삼채 추출물 $0.5 \mathrm{~mL}$ 와 $0.2 \mathrm{mM} \mathrm{DPPH} 0.5 \mathrm{~mL}$ 을 test tube에 취한 후 혼합하여 $37^{\circ} \mathrm{C}$ 에서 30 분간 반응시켜 UV-spectrophotometer (Bio-rad)를 사용하여 $517 \mathrm{~nm}$ 에서 흡광도를 측정하였다. 부위별 삼채 추출물의 DPPH radical 소거능은 $\{1$-(시료첨가 구의 흡광도/무첨가구의 흡광도) $\} \times 100$ 에 의하여 계산하 여 나타내었다.

\section{통계처리}

모든 실험은 독립적으로 3회 반복을 통해 얻었으며, 본 실험의 통계처리는 GraphPad Prism 5 program(GraphPad Software, Inc., La Jolla, CA, USA)을 이용하여 통계적 유의 성 검정은 $\mathrm{p}<0.05$ 수준일 때를 기준으로 하였다. 일원배치 분산분석(one-way analysis of variance)을 한 후, 각 시료간 의 통계적 유의성은 Tukey's multiple comparison test를 이 용하여 사후검증을 수행하였다.

\section{결과 및 고찰}

\section{일반성분 분석}

열풍건조와 동결건조에 따른 삼채 잎과 뿌리의 일반성분 분석은 Table 1 과 같다. 열풍건조 삼채 잎의 일반성분 함량 중 조회분 $19.03 \%$, 조단백 $24.38 \%$, 조지방 $7.56 \%$ 로 열풍건 조 삼채 뿌리의 조회분 $6.11 \%$, 조단백 $8.07 \%$, 조지방 $2.55 \%$ 에 비해 유의적으로 높음을 관찰하였다. 동결건조 삼채 잎 의 일반성분 함량은 조회분 $19.35 \%$, 조단백 $24.78 \%$, 조지방 $6.40 \%$ 로 동결건조 삼채 뿌리의 조회분 $6.17 \%$, 조단백 $7.38 \%$, 조지방 $1.64 \%$ 에 비해 유의적으로 높음을 관찰하였 으며, 조회분, 조단백, 조지방 성분은 건조방법에 상관없이 삼채의 뿌리보다 잎에서 높은 함량을 보였다.

건조 방법에 따른 삼채의 잎과 뿌리를 비교한 결과, 열풍
건조한 삼채 잎과 동결 건조한 삼채 잎의 수분 함량은 각각 $7.63 \%$ 와 $5.54 \%$ 로 유의적인 차이를 나타내었다. 조지방 성 분은 열풍 건조한 삼채 잎이 동결 건조한 잎보다 유의적인 증가를 보였으며, 뿌리의 경우도 이와 같은 경향을 보였다. 탄수화물의 경우, 건조방법에 대한 삼채의 잎과 뿌리의 일 반 분석 항목 중 가장 많은 함량을 나타내었으며, 이는 다른 Allium속 식물인 부추의 분석 결과와 유사한 결과를 보여주 었다(20).

Table 1. Proximate compositions of Allium hookeri treated with hot air and freeze dried methods

(\% dry basis)

\begin{tabular}{lcccc}
\hline \multirow{2}{*}{ Composition } & \multicolumn{2}{c}{ Hot air drying } & \multicolumn{2}{c}{ Freeze drying } \\
\cline { 2 - 5 } & Leaf & Root & Leaf & Root \\
\hline Moisture & $7.63 \pm 0.34^{1)}$ & $9.28 \pm 0.09^{\mathrm{a}}$ & $5.54 \pm 0.12^{\mathrm{b}}$ & $9.37 \pm 0.15^{\mathrm{a}}$ \\
Crude ash & $19.03 \pm 0.46$ & $6.11 \pm 0.60^{\mathrm{a}}$ & $19.35 \pm 0.67$ & $6.17 \pm 0.29^{\mathrm{a}}$ \\
Crude protein & $24.38 \pm 1.47$ & $8.07 \pm 0.40^{\mathrm{a}}$ & $24.78 \pm 0.61$ & $7.38 \pm 0.85^{\mathrm{a}}$ \\
Crude fat & $7.56 \pm 0.04$ & $2.55 \pm 0.17^{\mathrm{a}}$ & $6.40 \pm 0.30^{\mathrm{b}}$ & $1.64 \pm 0.05^{\mathrm{a}, \mathrm{b}}$ \\
Carbohydrate & $41.30 \pm 1.16$ & $72.22 \pm 1.16^{\mathrm{a}}$ & $45.13 \pm 2.84$ & $73.35 \pm 2.49^{\mathrm{a}}$ \\
\hline
\end{tabular}

${ }^{1)}$ All values are expressed as the mean $\pm \mathrm{SD}$ of triplicate determinations.

${ }^{\text {a }}$ Significantly different $(\mathrm{p}<0.05)$ between leaf and root extract within same drying method by one-way ANOVA followed by Tukey's multiple comparison test.

${ }^{b}$ Significantly different $(\mathrm{p}<0.05)$ between leaf and root extract within different drying method by one-way ANOVA followed by Tukey's multiple comparison test.

\section{유기산 함량 측정}

열풍건조와 동결건조에 따른 삼채의 잎과 뿌리의 유기산 함량은 Table 2와 같다. Oxalic acid, citric acid, tartaric acid, malic acid, succinic acid, lactic acid, formic acid, acetic acid 와 같이 총 8 종이 검출되었고, 이 중 acetic acid가 주된

Table 2. Contents of organic acids in hot air and freeze dried Allium hookeri

\begin{tabular}{|c|c|c|c|c|}
\hline \multirow{2}{*}{ Organic acids } & \multicolumn{2}{|c|}{ Hot air drying } & \multicolumn{2}{|c|}{ Freeze drying } \\
\hline & Leaf & Root & Leaf & Root \\
\hline Oxalic acid & $263.82 \pm 6.70^{1)}$ & $58.40 \pm 3.87^{\mathrm{a}}$ & $470.01 \pm 15.42^{b}$ & $128.77 \pm 5.87^{\mathrm{a}, \mathrm{ab}}$ \\
\hline Citric acid & $316.50 \pm 9.97$ & $411.37 \pm 12.32^{\mathrm{a}}$ & $195.40 \pm 7.16^{b}$ & $384.64 \pm 9.35^{\mathrm{a}, \mathrm{b}}$ \\
\hline Tartaric acid & $39.13 \pm 1.83$ & $62.36 \pm 3.37$ & $21.22 \pm 1.99$ & $442.30 \pm 20.80^{\mathrm{a}, \mathrm{b}}$ \\
\hline Malic acid & $66.83 \pm 1.42$ & $246.63 \pm 15.87^{\mathrm{a}}$ & $30.49 \pm 0.94^{b}$ & $316.05 \pm 10.53^{\mathrm{a}, \mathrm{b}}$ \\
\hline Succinic acid & $255.91 \pm 8.96$ & $21.72 \pm 1.73^{\mathrm{a}}$ & $139.98 \pm 4.76^{b}$ & $4.46 \pm 0.86^{\mathrm{a}, \mathrm{b}}$ \\
\hline Lactic acid & $459.43 \pm 5.92$ & $31.02 \pm 0.50^{\mathrm{a}}$ & $631.61 \pm 9.43^{b}$ & $4.08 \pm 0.50^{\mathrm{a}, \mathrm{b}}$ \\
\hline Formic acid & $213.74 \pm 15.96$ & $93.69 \pm 2.89^{\mathrm{a}}$ & $159.26 \pm 4.49^{\mathrm{b}}$ & $2.18 \pm 0.95^{\mathrm{a}, \mathrm{b}}$ \\
\hline Acetic acid & $2038.11 \pm 91.41$ & $313.04 \pm 5.71^{\mathrm{a}}$ & $2582.16 \pm 62.78^{b}$ & $15.73 \pm 0.40^{\mathrm{a}, \mathrm{b}}$ \\
\hline
\end{tabular}


유기산으로, 열풍건조한 삼채 잎에서 $2,038.11 \mathrm{mg} / 100 \mathrm{~g}$, 동결건조 삼채의 잎에서는 $2,582.16 \mathrm{mg} / 100 \mathrm{~g}$ 을 나타내었 다. 또한 열풍 건조한 삼채 뿌리에서는 citric acid 함량이 $411.37 \mathrm{mg} / 100 \mathrm{~g}$, 동결 건조한 삼채 뿌리에서는 tartaric acid 가 $422.30 \mathrm{mg} / 100 \mathrm{~g}$ 로 높게 나타났다.

건조방법에 따른 삼채 잎의 유기산 함량 차이를 살펴보 면, tartaric acid을 제외한 나머지 유기산 함량에서 유의적인 증가 또는 감소를 보였다. 또한 oxalic acid, tartaric acid, malic acid 함량은 열풍건조 삼채 뿌리에 비해 동결건조 삼채 뿌리에서 유의적으로 높게 나타났다. $\operatorname{Park}(7)$ 등의 연 구에서도 삼채 뿌리가 oxalic acid, tataric acid, malic acid, lactic acid, citric acid로 구성되었다고 나타나 본 연구결과 와의 유사성을 보여주었다.

\section{무기질 분석}

열풍건조 및 동결건조 삼채의 잎과 뿌리에 대한 무기질 분석은 Table 3 과 같다. 열풍건조 삼채 잎의 $\mathrm{Ca}, \mathrm{K}, \mathrm{Mg}$ 함량은 각각 $1,186.90 \mathrm{mg} / 100 \mathrm{~g}, 8,342.63 \mathrm{mg} / 100 \mathrm{~g}, 353.69$ $\mathrm{mg} / 100 \mathrm{~g}$ 이었고, 위의 함량은 다른 무기질 함량에 비해 열풍건조 및 동결건조 삼채의 잎과 뿌리에서 높은 함량을 보였다. $\operatorname{Park}(7)$ 등은 국내산 삼채 뿌리의 무기질 함량을 분석 한 결과, 본 연구와 유사하게 $\mathrm{Ca}, \mathrm{K}, \mathrm{Mg}$ 함량이 가장 높게 관찰되었음을 보여주었다. 또한, 건조방법에 따라 $\mathrm{Ca}$, $\mathrm{K}, \mathrm{Mg}$ 함량을 비교 하였을 경우, 열풍건조 삼채 뿌리와 동결건조 삼채 뿌리에서는 유의적인 차이가 관찰되지 않았 다. 그러나 동결건조 삼채 잎에 비해 열풍건조 삼채의 잎에 서 $\mathrm{Ca}, \mathrm{K}, \mathrm{Mg}$ 함량이 모두 유의적으로 높음을 나타내었다. $\mathrm{Fe}, \mathrm{Cu}, \mathrm{Mn}, \mathrm{Zn}$ 은 동일한 건조 방법 내에서 삼채 잎과

Table 3. Contents of minerals in hot air and freeze dried Allium hookeri

$(\mathrm{mg} / 100 \mathrm{~g})$

\begin{tabular}{ccccc}
\hline \multirow{2}{*}{ Organic acids } & \multicolumn{2}{c}{ Hot air drying } & \multicolumn{2}{c}{ Freeze drying } \\
\cline { 2 - 5 } & \multicolumn{1}{c}{ Leaf } & \multicolumn{1}{c}{ Root } & Leaf & Root \\
\hline $\mathrm{Ca}$ & $1186.90 \pm 67.15^{1)}$ & $97.59 \pm 5.16^{\mathrm{a}}$ & $961.23 \pm 35.48^{\mathrm{b}}$ & $94.16 \pm 5.16^{\mathrm{a}}$ \\
$\mathrm{K}$ & $8342.63 \pm 72.67$ & $2303.93 \pm 66.79^{\mathrm{a}}$ & $750.19 \pm 35.29^{\mathrm{b}}$ & $2183.67 \pm 75.94^{\mathrm{a}}$ \\
$\mathrm{Mg}$ & $353.69 \pm 4.94$ & $85.69 \pm 1.94^{\mathrm{a}}$ & $298.63 \pm 10.50^{\mathrm{b}}$ & $81.80 \pm 4.92^{\mathrm{a}}$ \\
$\mathrm{Fe}$ & $8.19 \pm 0.52$ & $26.46 \pm 1.89^{\mathrm{a}}$ & $7.14 \pm 0.56$ & $26.03 \pm 1.21^{\mathrm{a}}$ \\
$\mathrm{Cu}$ & $0.80 \pm 0.05$ & $0.34 \pm 0.05^{\mathrm{a}}$ & $0.70 \pm 0.05$ & $0.34 \pm 0.05^{\mathrm{a}}$ \\
$\mathrm{Mn}$ & $3.32 \pm 0.21$ & $2.62 \pm 0.10^{\mathrm{a}}$ & $3.04 \pm 0.09$ & $2.59 \pm 0.06^{\mathrm{a}}$ \\
$\mathrm{Zn}$ & $6.47 \pm 0.19$ & $1.64 \pm 0.06^{\mathrm{a}}$ & $6.25 \pm 0.31$ & $1.52 \pm 0.24^{\mathrm{a}}$ \\
$\mathrm{P}$ & $26.19 \pm 0.65$ & $25.10 \pm 1.69$ & $26.14 \pm 1.40$ & $23.86 \pm 0.33$ \\
$\mathrm{Na}$ & $40.68 \pm 2.26$ & $6.86 \pm 0.54^{\mathrm{a}}$ & $35.00 \pm 0.68^{\mathrm{b}}$ & $6.45 \pm 0.39^{\mathrm{a}}$ \\
\hline
\end{tabular}

${ }^{1)}$ All values are expressed as the mean $\pm \mathrm{SD}$ of triplicate determinations.

${ }^{a}$ Significantly different $(\mathrm{p}<0.05)$ between leaf and root extract within same drying method by one-way ANOVA followed by Tukey's multiple comparison test.

${ }^{b}$ Significantly different $(\mathrm{p}<0.05)$ between leaf and root extract within different drying method by one-way ANOVA followed by Tukey's multiple comparison test.
뿌리의 무기질 함량에 유의적인 차이를 보였으나, 건조방 법에 대한 차이는 보이지 않았다. $\mathrm{P}$ 의 경우는 동일 건조법 내에서 삼채 잎과 뿌리간의 함량 차이를 관찰하지 못하였으 며, 건조방법에 따른 차이 또한 보이지 않았다. Won 등(8)은 노지 및 시설재배 삼채 잎과 뿌리의 무기질 함량을 측정하 였으며, 본 연구 결과와 같이, 무기질의 종류는 동일하였으 나 함량의 차이는 다소 보였으며, 이는 열풍 및 동결건조로 인해 삼채의 무기질 함량 차이를 보였을 것이라 사료된다.

\section{비타민 분석}

열풍건조 및 동결건조 삼채의 잎과 뿌리에 대한 비타민 분석은 Table 4 와 같다. 열풍건조 삼채의 잎과 뿌리의 비타 민 $\mathrm{C}$ 함량은 각각 $801.65 \mathrm{mg} / 100 \mathrm{~g}$ 와 $255.78 \mathrm{mg} / 100 \mathrm{~g}$ 으로 뿌리보다 잎에서 유의적으로 높음을 관찰하였다. 동결건조 삼채 잎의 비타민 C 함량은 $460.25 \mathrm{mg} / 100 \mathrm{~g}$, 뿌리는 149.56 $\mathrm{mg} / 100 \mathrm{~g}$ 으로 열풍건조 삼채와 마찬가지로 잎에서 유의적 으로 높았다. 건조방법에 따른 비타민 $\mathrm{C}$ 함량은 열풍건조 삼채의 잎과 뿌리가 동결건조 삼채의 잎과 뿌리에서보다 유의적으로 높았다. You(21) 등의 삼채 뿌리의 비타민 C 함량과 비교해보았을 경우, 본 실험의 비타민 $\mathrm{C}$ 함량은 매우 높은 수치를 보였으며 이는 건조방법에 따른 차이뿐만 아니라, 삼채의 생육 조건에 대한 차이에서 나온 결과라 사료된다.

비타민 E의 함량은 열풍건조 삼채의 잎과 뿌리가 1.79 $\mathrm{mg} / 100 \mathrm{~g}, 0.19 \mathrm{mg} / 100 \mathrm{~g}$ 로 나타났고, 동결건조 삼채의 잎과 뿌리는 각각 $4.09 \mathrm{mg} / 100 \mathrm{~g}$ 과 $0.47 \mathrm{mg} / 100 \mathrm{~g}$ 로 열풍건조 삼채에 비해 동결건조 삼채가 높은 비타민 $\mathrm{E}$ 의 함량을 보여 주었다. 건조방법에 따라서는 열풍건조 삼채의 잎보다 동 결건조 삼채의 잎이 유의적으로 높게 나타났다.

Table 4. Contents of vitamin $\mathrm{C}$ and vitamin $\mathrm{E}$ in hot air and freeze dried Allium hookeri

\begin{tabular}{|c|c|c|c|c|}
\hline & \multicolumn{2}{|c|}{ Hot air drying } & \multicolumn{2}{|c|}{ Freeze drying } \\
\hline & Leaf & Root & Leaf & Root \\
\hline Vitamin C & $801.65 \pm 11.59^{1)}$ & $255.78 \pm 10.25^{\mathrm{a}}$ & $460.25 \pm 30.61^{\mathrm{a}, \mathrm{b}}$ & $149.56 \pm 6.60^{\mathrm{a}, \mathrm{b}}$ \\
\hline Vitamin E & $1.79 \pm 0.05$ & $0.19 \pm 0.05^{\mathrm{a}}$ & $4.09 \pm 0.22^{b}$ & $0.47 \pm 0.07^{\mathrm{a}}$ \\
\hline \multicolumn{5}{|c|}{$\begin{array}{l}{ }^{11} \text { All values are expressed as the mean } \pm \text { SD of triplicate determinations. } \\
\text { a Significantly different }(p<0.05) \text { between leaf and root extract within same drying } \\
\text { method by one-way ANOVA followed by Tukey's multiple comparison test. } \\
\text { b } \text { Significantly different }(p<0.05 \text { ) between leaf and root extract within different drying } \\
\text { method by one-way ANOVA followed by Tukey's multiple comparison test. }\end{array}$} \\
\hline
\end{tabular}

\section{총 polyphenol 및 총 flavonoid 함량}

천연물에 함유되어 있는 페놀성 화합물은 하나 이상의 벤젠링과 하나 이상의 수산기를 가지는 대사물질로 항산화 및 항염증에 효과가 있는 것으로 알려져 있다(22). 삼채의 열풍건조 및 동결건조에 따른 잎과 뿌리의 총 폴리페놀 
및 총 플라보노이드 함량을 분석한 결과는 Table 5 와 같다. 열풍건조 삼채의 잎과 뿌리의 총 폴리페놀 함량은 각각 $55.70 \mathrm{mg} / \mathrm{g}$ 과 $16.11 \mathrm{mg} / \mathrm{g}$ 이었고, 동결건조한 삼채의 잎과 뿌리는 각각 $60.75 \mathrm{mg} / \mathrm{g}$ 과 $11.86 \mathrm{mg} / \mathrm{g}$ 으로 관찰되었다. 건 조 방법에 따른 총 폴리페놀 함량은 삼채 뿌리에서 유의적 인 차이를 보였다. 또한 삼채 뿌리보다는 잎에서 총 폴리페 놀 함량이 높은 것을 확인할 수 있었고 이는 Lee(23) 등의 연구결과와 유사한 것으로 나타났다.

플라보노이드는 과일, 채소 등에 들어있는 폴리페놀 화 합물의 한 종류로, 식물체에서는 여러 당류와 에테르 결합 을 통해 배당체 형태로 존재한다(24). 총 플라보노이드 함량 은 열풍건조와 동결건조 모두에서 삼채 잎이 뿌리보다 높았 다. 건조 방법에 따른 총 폴리페놀 함량은 동결건조 삼채 잎이 열풍건조 삼채의 잎보다 유의적으로 높았다.

Table 5. Total polyphenol and flavonoid content of $80 \%$ ethanol extracts of hot air and freeze dried Allium hookeri

\begin{tabular}{ccccc}
\hline & \multicolumn{2}{c}{ Hot air drying } & \multicolumn{2}{c}{ Freeze drying } \\
\cline { 2 - 5 } & Leaf & Root & Leaf & Root \\
\hline Total polyphenol $(\mathrm{mg} / \mathrm{g})$ & $55.70 \pm 1.97^{1)}$ & $16.11 \pm 1.00$ & $60.75 \pm 3.22$ & $11.86 \pm 1.38^{\mathrm{a}}$ \\
\cline { 2 - 5 } Total flavonoid $(\mathrm{mg} / \mathrm{g})$ & $89.29 \pm 1.05$ & $4.13 \pm 0.10^{\mathrm{a}}$ & $131.82 \pm 1.76^{\mathrm{b}}$ & $2.93 \pm 0.05^{\mathrm{a}}$ \\
\hline 1) All values are expressed as the mean \pm SD of triplicate determinations. \\
${ }^{\text {a }}$ Significantly different $(\mathrm{p}<0.05)$ between leaf and root extract within same drying \\
method by one-way ANOVA followed by Tukey's multiple comparison test. \\
bignificantly different (p<0.05) between leaf and root extract within different drying \\
method by one-way ANOVA followed by Tukey's multiple comparison test.
\end{tabular}

\section{DPPH radical 소거능}

$\mathrm{DPPH}$ radical 법은 항산화 물질의 전자 공여능으로 방향 족 화합물 및 방향족 아민류 등에 의해 환원되면서 나타나 는 색의 변화로 인해 항산화 정도를 측정하는 방법이다(25). DPPH radical 소거능을 건조방법에 따른 삼채의 잎과 뿌리 로 나누어 측정한 결과는 Table 6과 같다. 열풍건조 잎과 뿌리는 각각 $65.73 \%$ 와 $53.02 \%$ 의 소거능을 보였으며 유의 적인 차이가 관찰되었다. 동결건조 잎과 뿌리는 $57.73 \%$ 와 $37.18 \%$ 의 DPPH radical 소거능을 나타내어 동일한 건조방 법 내에서 뿌리보다 잎이 유의적으로 높은 DPPH radical 소거능을 보여주었다. 이는 $\operatorname{Hwang}(6)$ 등의 메탄올로 추출

Table 6. DPPH radical-scavenging activity of $80 \%$ ethanol extracts of hot air and freeze dried Allium hookeri

\begin{tabular}{|c|c|c|c|c|}
\hline & \multicolumn{2}{|c|}{ Hot air drying } & \multicolumn{2}{|c|}{ Freeze drying } \\
\hline & Leaf & Root & Leaf & Root \\
\hline $\begin{array}{l}\text { DPPH radical scavenging } \\
\text { activity (\%) }\end{array}$ & $65.73 \pm 1.97^{1)}$ & $53.02 \pm 2.49^{\mathrm{a}}$ & $57.73 \pm 1.61^{b}$ & $37.18 \pm 2.64^{a, b}$ \\
\hline \multicolumn{5}{|c|}{$\begin{array}{l}\text { 1) All values are expressed as the mean } \pm \text { SD of triplicate determinations. } \\
\text { a Significantly different }(p<0.05) \text { between leaf and root extract within same drying } \\
\text { method by one-way ANOVA followed by Tukey's multiple comparison test. } \\
\text { bignificantly different }(p<0.05) \text { between leaf and root extract within different drying }\end{array}$} \\
\hline
\end{tabular}

한 삼채의 DPPH radical 소거능 연구 결과와 유사한 경향을 보여주었다. 건조방법에 따른 DPPH radical 소거능은 열풍 건조 삼채의 잎과 뿌리가 동결건조 삼채의 잎과 뿌리보다 유의적으로 높음이 관찰되었다.

\section{요 약}

본 연구는 삼채의 잎과 뿌리를 이용하여 열풍건조와 동 결건조법에 따른 이화학적 성분, 총 폴리페놀, 총 플라보노 이드 함량 및 항산화력을 비교 분석하였다. 건조방법에 따 른 삼채 잎의 일반성분을 분석한 결과, 조회분, 조단백, 탄수 화물 함량은 유의적인 차이를 보이지 않았다. 그러나 열풍 건조 삼채 잎의 수분 함량과 조지방 함량은 동결건조 삼채 잎보다 유의적으로 높았다. 열풍건조 삼채 뿌리의 수분, 조회분, 조단백, 탄수화물 함량은 동결건조 삼채 뿌리와 유의적인 차이가 없었으며, 조지방 함량만이 동결건조 삼 채 뿌리보다 유의적으로 높게 나타났다. 삼채 잎과 뿌리에 서의 유기산 함량을 비교한 결과, 열풍건조 삼채의 뿌리는 동결건조 삼채 뿌리에 비해 oxalic acid, citric acid, tartaric acid, malic acid, succinic acid, lactic acid, formic acid, acetic acid에서 유의적인 차이를 보였다. 열풍건조 삼채의 잎은 tartaric acid를 제외한 모든 유기산 항목에서 동결건조 삼채 의 잎과 비교하여 유의적인 차이를 보여주었다. 건조방법 에 따른 삼채 잎과 뿌리의 주요 무기질은 $\mathrm{Ca}, \mathrm{K}, \mathrm{Mg}$ 이며, 이들은 열풍건조 삼채 잎에 비해 동결건조 삼채 잎에서 유의적으로 낮게 나타났다. 비타민 $\mathrm{C}$ 의 함량은 동결건조 삼채의 잎과 뿌리에 비해 열풍건조 삼채의 잎과 뿌리에서 유의적으로 높았다. 비타민 $\mathrm{E}$ 는 열풍건조 삼채 잎에 비해 동결건조 삼채 잎에서 유의적으로 높게 나타났으나, 뿌리 에서는 유의적인 차이를 보이지 않았다. 총 polyphenol 함량 은 동결건조 삼채의 잎이 열풍건조 삼채의 잎에 비하여 높았으나 유의적인 차이는 없었으며, 총 flavonoid 함량은 동결건조 삼채의 잎이 열풍건조 삼채의 잎에 비하여 유의적 으로 높았다. 삼채의 DPPH radical 소거능은 삼채 잎과 뿌리 에서 건조방법에 따른 유의적인 차이를 보였으며, 삼채 뿌 리보다 삼채 잎에서 DPPH radical 소거능이 더 뛰어남을 보였다.

\section{References}

1. Ayam VS (2011) Allium hookeri, Thw. Enum. A lesser known terrestrial perennial herb used as food and its ethnobotanical relevance in Manipur. Afr J Food Agric Nutr Dev, 11, 5389-5412

2. Shee HJ (1999) The antibacterial action of garlic, onion, 
ginger and red pepper juice. J Korean Soc Food Sci Nutr, 28, 94-99

3. Choi JS, Kim YJ, Lee JH, Young HS, Lee JW (1992) Isolation of adenosine and free amino acid composition from the leaves of Allium tuberosum. J Korean Soc Food Sci, 21, 286-290

4. Rhyu DY, Park SH (2013) Characterization of alkyl thiosulfinate in Allium hookeri root using HPLC-ESI-MS.

J Korean Soc Appl Biol Chem, 56, 457-459

5. Ayam VS (2011) Allium hookeri, Thw. Enum. A lesser known terrestrial perennial herb used as food and its ethnobotanical relevance in Manipur. Afr J Food Agric Nutr Dev, 11, 6

6. Hwang JS, Lee BH, An Xiangxue An, Jeong HR, Kim YE, Lee I, Lee HJ, Kim DO (2015) Total phenolics, total flavonoids, and antioxidant capacity in the leaves, bulbs, and roots of Allium hookeri. J Korean Soc Food Sci Nutr, 44, 832-839

7. Park JY, Yoon KY (2014) Comparison of the nutrient composition and quality of the root of Allium hookeri grown in Korea and Myanmar. Korean J Food Sci Technol, 46, 544-548

8. Won JY, Yoo YC, Kang EJ, Yang H, Kim GH, Seong BJ, Kim SI, Han SH, Lee SS, Lee KS (2013) Chemical components, DPPH radical scavenging activity and inhibitory effects on nitric oxide production in Allium hookeri cultivated under open field and greenhouse conditions. J Korean Soc Food Sci Nutr, 42, 1351-1356

9. Jeong SJ, Kim KH, Yook HS (2015) Whitening and antioxidant activities of solvent extracts from hot-air dried Allium hooker. J Korean Soc Food Sci Nutr, 44, 832-839

10. Jun HI, Jang HN, Yang JH, Song GS, Kim YS (2015) Physicochemical properties and antioxidant activities of steam-dried Allium hookeri root. J Korean Soc Food Sci Nutr, 44, 412-417

11. Kwon GM, Kim JW, Youn KS (2013) Effect of different pre-treatments on the physicochemical and antioxidant activities of cold-vacuum dried peaches. Korean J Food Sci Technol, 45, 466-472

12. Park NH (1995) General outline and status of application for freeze-drying. J Air-Condi Refr Eng, 24, 338-345
13. Hong JH, Lee WY (2004) Quality characteristics of osmotic dehydrated sweet pumpkin by different drying methods. J Korean Soc Food Sci Nutr 33, 1573-1579

14. AOAC (1997) Official methods of analysis. 16th ed. Association of Official Analytical Chemists (No. 934.06), Arlington, VA, USA

15. Kim DH, Lim DW, Bai S, Chun SB (1997) Fermentation characteristics of whole soybean meju model system inoculated with 4 Bacillus strains. Korean J Food Sci Technol, 29, 1006-1015

16. Ministry of Food and Drug Safety (2005) Korean Foods standards codex. Korean Food Industry Association. Seoul, Korea, p 383-385

17. Singleton VL, Rossi JA (1965) Colorimetry of total phenolics with phosphomolybdic-phosphotungstic acid reagents. Am J Enol Vitric, 16, 144-158

18. Folin O, Denis W (1912) On phosphotungastic phosphomolybdic compounds as color regents. J Biol Chem, 12, 239-249

19. Blois MS (1958) Antioxidant determinations by the use of a stable free radical. Nature, 181, 1199-1203

20. Lim TS, Oh HI, Do JR, Kim HK (2006) Physiological activities of leek extracts from Allium tuberosum and Allium senescens. J Korean Soc Food Sci Nutr, 35, 301-306

21. You BR, Kim E, Jang JY, Choi HJ, Kim HJ (2013) Quality characteristics of kimchi with Allium hookeri root powder added. Korean J Food Preserv, 20, 863-870

22. Rice EC, Nicholas M, George P (1997) Antioxidant properties of phenolic compounds. Trends Plant Sci, 2, 152-159

23. Lee KW, Kim YS, Park PJ, Jeong JH (2014) Comparison of effect of water and ethanolic extract from roots and leaves of Allium hookeri. J Korean Soc Food Sci Nutr, 43, 1808-1816

24. Heim KE, Tagliaferro AR, Bobilya DJ (2002) Flavonoid antioxidants: chemistry, metabolism and structure-activity relationships. J Nutr Biochem, 13, 572-584

25. Sharma OP, Bhat TK (2009) DPPH antioxidant assay revisited. Food Chem, 113, 1202-1205 